\title{
On the Future Economy of Capture Fisheries and the Future Consumer Market for Fish
}

\author{
Hachiro Ikeda \\ Special Advisor, Japan Deep Sea Trawlers Association \\ 601 Ogawamachi Yasuda Bldg., 3-6 Kanda Ogawa-cho, Chiyoda-Ku, Tokyo 101
}

\begin{abstract}
In this paper the author discusses the future of capture fisheries and the consumer market from the perspective of an experienced fisherman and the Japanese consumer. Projected world fishery production by 2010 is viewed as likely to fall short of the projected demand for human consumption. From the FAO projected range of 74-114 million tons by 2010, the author suggests a likely range between 80 and 90 million tons. The author's projection predicts an increased consumer demand in the range of 110-120 million tons by 2010 , similar to FAO projections. Arguments are presented to justify these projections, and sends a clear message for far-reaching improvement in the utilization and management of marine resources and protection of the marine environment.
\end{abstract}

Key words: consumer demand, fish consumption, fishery production

\section{Introduction}

In this paper, the author discusses the future of capture fisheries and the consumer market from the perspective of an experienced fisherman and Japanese consumer. It is therefore appropriate to describe the knowledge base and experience of the author first.

Mr. Ikeda spent the first 12 years of his career in the 1960s and early-1970s as an officer on board a Japanese distant-water fishing vessel owned and operated by one of Japan's largest fishing companies. Japanese distant-water fishing vessels spent months on end at sea during those years providing its officers with experience on the major fishing grounds of the world harvesting and processing fish for one of the world's largest consumer markets for fishery products; Japan. Mr. Ikeda then returned to the company head offices in Japan where for the next 15 years, as a manager of the marine personnel section, he was involved in joint venture fishery operations with Ghana, Guinea, Angola, Ireland, Australia, Indonesia, Chile, Argentina, Russia and the United States. He now serves as special advisor to the Japan Deep Sea Trawlers Association. Mr. Ikeda's first-hand experience with the problems facing capture fisheries and their ability to fulfill the increasing world demand for fishery products is presented in this paper. A review of historic data and projections of conditions into the future are used to send a clear message for farreaching improvement in the utilization and management of marine resources and protection of the marine environment.

\section{World Production and Demand by 2010}

In general it is possible to say projected world fishery production by 2010 will fall short of the projected demand for human consumption. The outlook for the future economy of capture fisheries would therefore appear good. But this outlook would be short-sighted without improved efficiency in utilization and effective management measures to conserve fishery resources and protect their environment.

World Production. The Fisheries and Agricultural Organization of the United Nations (FAO) projects world fishery production by 2010 will range between 74 million tons from a pessimistic viewpoint and 114 million tons from an optimistic viewpoint (FAO, 1997a).

I am inclined to think the FAO projection may be slightly over optimistic, while the world fishery production in recent years at 73.73 million tons in 1993, 76.60 million tons in 1994 and 79.92 million tons 
(preliminary) in 1995 (FAO, 1997b), has been closer to the FAO's pessimistic viewpoint. Nor is there any explanation for the 40 million ton difference between the pessimistic and optimistic viewpoints. If this difference is to be filled mainly by increased production from fresh-water aquaculture, then I cannot help but say that the FAO projection is excessively optimistic. One can foresee underlying problems associated with the availability of aquaculture sites and the lack of water supply and feed.

There are several problems working against the optimistic viewpoint. One problem is environmental degradation in coastal waters. Land reclamation, city sewage discharges, agricultural and industrial waste water discharges, and expanding aquaculture have accelerated the destruction of spawning and rearing grounds for marine living resources and contaminate their marine environment.

Another problem is improper management of fishery resources. Currently more than $2 / 3$ of the world's stocks are fished at or beyond the level of maximum productivity. FAO figures show more specifically that $25 \%$ of the stocks are either overexploited or already depleted because of overfishing. Another $44 \%$ are fished at their biological limit and in danger of over-exploitation if fishing pressure continues. Only $31 \%$ of the stocks are fished at an acceptable level (FAO, 1997c).

The third problem is waste. Each year 27 million tons of fish are discarded, equivalent to about $1 / 3$ of the total world production (Alverson et al., 1994). Under-utilized species, which could be processed into human food, make up a large portion of the discards in many fisheries.

The FAO is urgently calling for national implementation of the "Code of Conduct for Responsible Fishing". However, even if the Code could be implemented by 2000, it is quite difficult to imagine that positive effects can be achieved by 2010. Rather, there is a strong possibility problems will become more evident, particularly in the western Pacific with that region's remarkable increase in human population and economic growth. Moreover, if oceanographic changes caused by global warming are taken into account, which I consider to be affecting fishery resources unfavourably, I am compelled, even taking an optimistic stance, to adopt figures closer to the FAO's pessimistic projections. My projection for world fishery production by 2010 is between 80 and 90 million tons.

Demand. The FAO predicts a rapid increase in demand by 2010, within a range of 110-120 million tons, due to population growth and increase in individual disposable income for food (FAO, 1997c). My projection is similar to that of the FAO. Here I have taken a conservative stance in my projection, giving thought to the world population increase and the increasing consumption of fish as a source of protein. The Asia Pacific countries with continuing economic growth, a rising standard of living, and values which steer their protein needs toward fish as opposed to other protein sources are given special consideration in my projection.

Currently the middle-class population in Asia, mainly in China and India, is 200-300 million. If the current pace of economic growth can be sustained, it is anticipated this middle-class will increase to 800 million-1 billion by 2010. The countries subject to increasing fish consumption with these expanding middle classes are China, India, Malaysia, Pakistan, the Philippines, Thailand and Viet Nam.

I do not anticipate an increase in consumption among the countries in economic transition, such as the Eastern European nations, the former Soviet bloc nations, as well as the African nations. Nor do I anticipate an increase in consumption in Japan if fish prices continue to rise as expected. In fact, I would project only a slight decrease in Japanese consumption along with a decrease in the western developed countries. But the decrease in these developed countries will be more than offset by the increase in the Asia Pacific nations.

The Deficit. I have projected that world fishery production by 2010 will be $80-90$ million tons whereas demand will be 100-120 million tons. The deficit is about 10 million tons from an optimistic viewpoint and 40 million tons from a pessimistic viewpoint. "Nature" magazine (Nature, 1997) projects a deficit closer to the median at 19 million tons. My instinctive feeling is a 20 million ton shortage. 
The deficit can also be roughly expressed by subtracting the deficiency in production by the major fish consuming nations from the surplus in production by fish producing nations. By 2010, I project that Japan, the EU and Asia will suffer a deficiency in production of about 25 million tons, whereas Canada, the U.S., Argentina, New Zealand, Australia, Norway, Peru and Chile will produce a surplus to their needs of about 5 million tons. This surplus will be exported to the major fish consuming nations leaving a deficit still at about 20 million tons in 2010 .

Under the circumstances, "New Scientist" magazine states that the era of fish being a poor man's protein shall pass into eternity (New Scientist, 1996). A scenario predicted for 2010 is one of a desperate fish war with fish being classified as a luxury item. All the more reason for urgency in implementing the FAO Code of Conduct for Responsible Fishing and the Precautionary Approach.

\section{Effects Upon Japan as a Fish Consuming Nation}

Japan's fishery production in 1994 was 8.1 million tons, ranking 3rd after China (25.63 million tons) and Peru (11.59 million tons) (FAO, 1997b). But the value of Japan's fishery product imports stands at the top.

In 1994, Japan imported 3.296 million tons of fishery products. In 1995 imports increased by $9 \%$ in volume to 3.58 million tons and $1 \%$ in value to US $\$ 18.4$ billion, equal in value to $1 / 3$ of Japan's total food imports. By major country of origin and by value, the U.S. is first with $13 \%$ of the total value followed by China, Thailand, Russia and Indonesia. The cumulative imports from these 5 high-ranking countries amount to $48 \%$ of the total imports by value (based upon the type of product at the time of customs clearance).

However, for the first time in 7 years, Japan's import of fishery products in 1996 declined $3.7 \%$ from the previous year to 3.45 million tons (FAO, 1997b). Yet due to a weakened Yen, the value of imports in 1996 surpassed the previous record high in 1995 of $11.1 \%$ reaching 1,913.5 billion Yen. Though a weakened Yen and other factors, such as the E. coli breakout in 1996, may account for a decrease in imports, as a fish consuming nation, the decrease evidences a tightening situation over imports and indicates that demand is nearing a significant shifting point.

However, as a fish consuming race, Japanese consumption still remains strong. (Note: Japan's per capita consumption stands at $70.9 \mathrm{~kg}$, about 5 times the world's average of $13.9 \mathrm{~kg}$. Even though the Japanese have become economically more affluent, their need for protein has not shifted to meat but has remained with marine products. Younger Japanese prefer meat products, but they tend to shift their preferences, as they become older. So, as Japan heads into the 21 st century and the composition of seniors in her population increases, it is thereby anticipated that demand will remain strong.) Consumption increased to 8.36 million tons (round weight) in 1994 and 8.9 million tons in 1995 . In 1995, the daily per capita consumption of animal protein was $48.5 \mathrm{~g}$, composed of $19.5 \mathrm{~g}$ of marine products (40\% of the total intake), $15.5 \mathrm{~g}$ of meat products $(32 \%)$, and $13.4 \mathrm{~g}$ of egg and dairy products (27\%). This ratio has hardly changed for the past 5 years.

But given the projected 20 million ton shortage by 2010 and the increasing price of fish in the Japanese market, I am inclined to think it will be impossible for Japan to maintain her current per capita level of consumption. Japan will probably receive the most critical blow once we move into the "fish-deficiency era".

\section{The Future of Capture Fisheries}

There are few people who question the increasing demand for fish on a global basis. The projected demand for fish could have extensive implications for fishery resources around the world. When fish prices rise it is a common tendency for fishermen world-wide to pursue shorted sighted profits. Anticipated behaviour would lead to practices of overfishing and the capture of juvenile fish. Fish buyers and importers are among those who stimulate such behaviour. Subsequent resource depletion would become evident in many fisheries. 
How can we avoid this scenario? It is becoming clear that aquaculture is not a panacea for supplementing the demand. It pollutes the oceans, particularly the coastal areas, and it is destructive to the ecology for marine living resources. Fish disease is common with aquaculture species. The supply of aquaculture feed is insufficient. And there is a lack of water supply for fresh water aquaculture. The only way to meet the demand is to rely on capture fisheries. But the reliability of capture fisheries is conditioned upon the implementation of several measures to ensure the sustainability of world fishery resources.

Protection of the fisheries environment. There are several difficult problems, which must be addressed, particularly in the western Pacific extending from the waters off Russia to those off Southeast Asia. These problems include:

- the contamination of water quality from land-based sources such as household sewage in high density population centres and discharged waste water from agriculture and other industries,

- the destruction of spawning and rearing grounds by land reclamation and over development of coastal regions, and

- the contamination of water quality and the undesirable impacts on marine habitat and the diversity of marine living creatures resulting from the loss of marshes and mangrove swamps to increasing numbers of aquaculture facilities.

Basically, these problems must be resolved at the regional level. Regional agreements will be necessary to protect and rehabilitate the coastal marine habitat. However, attitudes toward resolving these problems are actually negative in the developing nations where industrialization is given priority. There is a lack of recognition for environmental issues in favour of achieving immediate development goals. (Note: Japan experienced similar marine environmental problems 30 years ago. But the fishing industries in the developing countries have yet to learn from the Japanese experience and understand the long-term consequences, which plagued the Japanese fisheries for the sake of short-term industrialization.)

Accelerate the advancement of fisheries science. There are many aspects of the oceans and its living resources, which still remain far from, understood. Even when oceanic conditions are comparatively stable, management of marine living resources is extremely difficult as experienced by the world's leaders in fisheries science, such as Europe, the United States and Canada. Still more, if oceanic changes occur, such as the Great Salinity Anomaly in the Atlantic Ocean and El Nino in the Pacific Ocean, those resources may change drastically or even become extinct.

Decisively implement fishery closures. Fisheries should be decisively closed upon any indication of instability in resource conditions. Notwithstanding the economic and social pressures that confront such decisive actions, the long-term impacts of such instability must be foremost in the considerations. This obviously relates to a sound scientific knowledge of the resource conditions.

Develop programs to respond to times of instability. Compensatory measures should be implemented to ease the anxieties of those affected by a closure. Opportunities should be extended to the fisheries workforce to learn skills that are interchangeable with those of land-based industries. Fisheries technologies often fit the fishing industry only.

Pursue profits through extensive cost cutting measures. When prices increase, it is common for fishermen to pursue short-sighted profits through practices leading to overfishing. Therefore, it is necessary to refocus the profit motive upon the reduction of costs. No matter how one looks at it, efficiency in the fisheries is inferior to that in shore based industries. This may be unavoidable since fisheries are dealing with nature. For example, the cost of equipment, including fishing vessels, is generally higher because the production is quite often custom ordered. More standardized equipment is needed.

Increase utilization. There are several answers to this challenge. Once answer lies in converting under-utilized resources and species mainly used for non-human consumption, such as sardine, into foods 
for human consumption. Among the species caught and discarded by Western nations, there are a substantial number that could be utilized for human food. When one looks at the fish eating traditions world wide, the definition for low, medium and high preference fish becomes increasingly ambiguous. For example, in the western region of Japan, cod, which is preferred in western nations and northern Japan, is not a high preference fish. Squid and mackerel are preferred there instead.

Reduce waste through post-harvest technology. The most desirable scenario is to catch the fish as needed (just-in-time system). Unfortunately, this is not always practical. Since there has not been appreciable progress in the development of post-harvest technology, such as freezing, quality deteriorates resulting in lower prices or waste. There are many other areas for improvement in post-harvest technology.

\section{Conclusion}

The twenty-first century is said to be the century of population, food and environment. Fish is probably a front runner on the issue of food. Capture fisheries have a hopeful future when you look at the demand and supply, but for a commodity with a constantly strained supply, stringent management based upon precautionary principles will be required. The wisdom of mankind is at stake in overcoming the problems facing the future of capture fisheries.

\section{References (including suggested reading*)}

ALVERSON, D. L., M. H. FREEBERG, J. G. POPE, and S. A. MURAWSKI. 1994. A global assessment of fisheries by-catch and discards. FAO Fish. Tech. Paper, 339, 19 p.

*CUSHING, D. 1995. Population production and regulation in the sea, Cambridge, 160 p.

FAO. 1997a. Internet reports on fishery statistics, January, February and April, 1997.

1997b. FAO Yearbook., fishery statistics 1995. FAO Fisheries Series, Volume 81, No. 45.

1997c. Review of the state of world fisheries and aquaculture. Fisheries Cir, No. 920.

*Far Eastern Economic Review. 1997. 50th Anniversary Issue.

*Fisheries White Paper in Japan. 1997. Fisheries Agency, Government of Japan, p. 24-28.

*Fishing News International, November 1996.

*LAEVESTU, T., D. L. ALVERSON, and R. MARASCO. 1996. Exploitable marine ecosystems: their behaviour and management. Fishing News Books, Farnham, United Kingdom, p. 162-166.

*NAISBITT, J. 1996. Megatrends, Asia, Nicholas Brealey Publishing Limited, 37 p.

NATURE. 1997. The issue of 13 March 1997, 107 p.

NEW SCIENTIST, 1996. Blue Revolutionaries, issue of 7 December 1996, p. 32-35.

* State of the World, World Watch Institute, 1995, 1996 and 1997.

*Vital Signs, World Watch Institute, 1996, p. 25-30.

*WORLD RESOURCES. 1996. A joint publication by the World Resources Institute and the United Nations Environment Program. Oxford University Press, 1996. 
